Fecha de recepción: marzo 2008 Fecha de aceptación: mayo 2008 Versión final: noviembre 2008

\section{La tecnología se sepulta a sí misma}

Augusto Zanela ${ }^{(*)}$

\footnotetext{
${ }^{(*)}$ Arquitecto (UBA). Director y docente del Taller de Fotografía (UBA). Profesor Titular en la Escuela de Comunicación Multimedial de la Universidad Maimónides. Docente del área de Fotografía en el Centro Cultural Rector Ricardo Rojas.
}

Resumen: Este ejercicio de escritura descriptiva podría interpretarse, de algún modo, como un intento de congelar un instante (como en una fotografía) de un momento histórico confuso, cambiante, que rápidamente olvida o abandona a su suerte todo aquello de lo que no se lleve registro, y que si se registra pasará a ser una más de las tantas cosas que a diario nos pide a gritos que le prestemos un momento de atención en medio del universo de estímulos con que convivimos.

O (también), como trataría de cosas del pasado, podría leerse como una posibilidad de traer al presente una serie de estampas que nos permitirían recrear la historia de un determinado personaje que parabólicamente involucra la de varios. Algo así como hurgar en su álbum de fotos para reconstruir el guión de su vida para emprender el de su grupo social.

También, para organizar el relato, se divide el texto en pequeños capítulos, que llevan como título la edad de nuestro personaje al momento en que se cuenta la experiencia, que pueden no ser cronológicos, y que en caso de versar sobre cuestiones generales de su vida, como por ejemplo el país de origen, puede llevar directamente el nombre del tema que aborda.

Palabras claves: Argentina contemporánea - cisma - digital - educación - fotografía - imagen - tecnología.

[Resúmenes en inglés y portugués en las páginas 158-159]

\title{
Argentina
}

El país de origen de nuestro personaje sería sin duda Argentina, tierra indomable que entrena a sus habitantes en el difícil arte de la supervivencia mediante cíclicos saltos al vacío, que se suceden con una periodicidad tal que los ubica entre los más altos puestos a nivel mundial de adaptación a lo inexplicable. No creería necesario ahondar aquí en más detalles sobre este país, ya que irán apareciendo a lo largo del ensayo como referencias contextuales que echarán luz sobre algunas de las cuestiones que le tocaron vivir al personaje en la ficción (pero que pertenecen a una de esas tantas realidades que la superan).

\section{La imagen}

Su vínculo con la imagen, al igual que para la gran mayoría de las personas de su generación, no estuvo dado ni por el estímulo familiar ni por la educación formal, ya que la relación de los padres con la 
imagen -especialmente con la fotografía-, era prácticamente nula, y de la formación sobre cuestiones artísticas en la escuela pública de su barrio no hay mucho para decir. En la mayoría de los hogares que hubiera podido frecuentar durante su infancia y primeros años de la adolescencia no había cámaras fotográficas (ni de cine doméstico), y en caso de que las hubiera, no estaban al alcance de un niño bajo ninguna circunstancia, por considerárselos no aptos. Además, esta veda alcanzaba a toda la planta tecnológica con que contaba una familia. La tecnología no dominaba el hogar argentino de mediados de los sesenta hasta fines de los setentas, y no parecía ser una preocupación fundamental entre sus integrantes alejados como estaban, geográfica y económicamente, de los circuitos internacionales de producción y consumo. Se viajaba muy poco al exterior, no se tenía ni idea de los precios internacionales de la mayoría de los productos (a excepción de tabaco y alcohol, souvenir obligado de cualquier viaje), se dudaba si los equipos tecnológicos extranjeros funcionarían bajo el régimen local, y no se conocía nada sobre los nuevos lanzamientos ni adelantos de una industria que luego se ocuparía de manera sistemática de informar sus novedades al punto de crear generaciones de consumidores compulsivos tecnodependientes. Los aparatos que allí encontrábamos eran robustos equipos, ninguno electrónico, ninguno importado, que no exigían ningún esfuerzo intelectual para operarlos, y que se esperaba que duraran toda una vida. La diferencia con los equipos contemporáneos, ligeros, remotos y excedidos en funciones, era notable. Aquellos equipos con que contaba el hogar de clase media estaban diseñados para un único destino. Se tenía por normal la multiplicidad de aparatos, cumpliendo cada uno su singular cometido en el ambiente de la casa donde se instalaba para siempre. El teléfono era sólo eso (si lo había), la radio, también. La única excepción la constituía el combinado, que dominaba la sala: mueble multifunción que albergaba una radio, un tocadiscos, el sistema de amplificación y dos parlantes, en un diseño que también contemplaba un espacio para el almacenamiento de los pocos discos con que contaba la familia, y que sólo sonaban en algún que otro evento donde no se ponía la radio como sonido de fondo en una emisora que transmita música. Las tapas de esos vinilos formaban parte del reducidísimo imaginario que poblaba la casa, pero dada la escasa circulación que tenían dentro del diario universo familiar, difícilmente hayan quedado impresionados en la retina. Esta poca circulación de música grabada envuelta en imágenes evidenciaba claramente una brecha (un abismo) entre las creencias de los padres y los hijos, entre aquellos que sólo escuchaban la música que sonaba en el programa de radio al cual seguían y éstos que consumieron música envasada en varios formatos a lo largo de su vida, de la que el arte de tapa -la foto del ídolo- pasaría a ser uno de los más preciados objetos devocionales, al punto de convertir el cuarto de los más jóvenes en algo semejante a un templo, en una actitud -según sus mayores- de un paganismo equiparable a la adoración del becerro de oro. Esto se dio tal vez como consecuencia de la lógica de consumo que diferenció ambas generaciones: una tuvo que ir personalmente a conocer el mundo, mientras la otra lo puede hacer desde el confort doméstico; una fue educada en valores que se suponían básicos para el funcionamiento colectivo de una sociedad, la otra fue bombardeada por una propaganda que alienta el consumo individual como forma de pertenencia a determinada tribu. El resto de los singulares aparatos que constituían el paisaje doméstico eran la radio a transistores y el televisor valvular. La radio, tal vez como aparato más importante, como auténtica conexión con el mundo exterior (local), como vínculo con los sucesos de actualidad, como entretenimiento. Todas las grandes noticias aparecían primero en la radio, todos los anuncios y presentaciones se hacían por radio, había transmisión todo el día. La radio, como dispositivo, estrenó el concepto de portabilidad. La radio, como medio, el de la participación de la audiencia. Para un niño era el primer aparato que llevaba pilas, y que tenía un tamaño que le permitía llevarlo de un lado para el otro de la casa 
(siempre a pedido y bajo la mirada atenta de un mayor), y hasta venía una en el auto (si lo había); la televisión a válvulas, en blanco y negro, comprada con suficiente antelación para ver en la comodidad del hogar la llegada a la luna, sólo transmitía unas pocas horas por día, y su programación distaba de contemplar a los niños como consumidores extremos. Sin embargo, no podría dejar de señalar un ejercicio al que sometía a nuestro pequeño espectador, sentado en el piso del living frente a una alta mesa que soportaba el televisor (y el estabilizador de corriente: importantísimo), y es el del pasaje de la imagen color, con su contraste cromático naturalmente excitante, a la de la desteñida paleta de grises que brindaban esas viejas pantallas. Vistos a la luz del televisor actual reducido de color, las imágenes, sobre todo de los dibujos animados de esa época, se aprecian con una falta de contraste tonal bastante pronunciada, tornándolas como si estuvieran veladas o alteradas en su brillo. Este ejercicio tenía consecuencias notables, sobre todo en el momento de dibujar y pintar. Los personajes cuyo color no estaba dado en su nombre, se pintaban del color que a uno se le ocurriera. La pantera era siempre rosa, pero el oso hormiguero no era para todos azul. Los manuales de instrucciones de todos esos aparatos eran piezas de diseño comunicacional de una simplicidad asombrosa porque sólo debían instruir sobre las funciones elementales para las que fueron diseñados esos dispositivos, y hasta las personas de más edad, naturalmente alejadas de las comodidades que ofrecían las modernas maravillas del hogar, podían entenderlos y por consiguiente, operarlos. Se podría pensar que la industria de esa época no generaba discapacitados tecnológicos, a pesar de no estar aún vinculada con el concepto de "user friendly", esto es, la voluntad actual de los productores tecnológicos de simplificar al extremo las posibilidades de manipulación y programación de los sofisticados equipos al permitir que el mismo aparato cuente con los dispositivos necesarios para analizar las mejores condiciones sobre las cuales operar y actúe en consecuencia, permitiendo que el usuario sólo tenga necesidad de activar el dispositivo y disfrutar del resultado.

Y si por casualidad había una cámara de fotos en la casa, casi seguro era alguna de aquellas elementales cámaras compactas que se popularizaron en esa época, producidas íntegramente de plástico (desde el display donde se presentaba hasta su óptica), que disponían la película en un cartucho hermético, con lo que las posibilidades de inconvenientes se reducía a cero, y que obtenían imágenes que eran, la mayoría de las veces, ininteligible. Las condiciones para que se registre una foto con calidad aceptable sólo estaban dadas en el exterior con máxima iluminación diurna, por lo que resulta fácil entender la escasa construcción de la cotidianeidad interior en el álbum de fotos familiares de la época. La foto en interiores que sí aparece es la del evento festejado en casa (el brindis, o soplando las velitas), iluminado por uno de los cuatro disparos que permitía el flash descartable, uno de los pocos motivos que justificaban el gasto.

En caso de que cualquier niño estuviera interesado en algún aspecto de la imagen, las posibilidades con que contaba para educarse eran que con suerte la mamá lo inscriba (y lo lleve) al taller de la profesora de pintura del barrio, o investigar por su cuenta a través de ciertas revistas de historietas, que aún se publican y que, entre otras cosas, promocionaban en toda la dimensión de sus pequeñas y apaisadas páginas una variedad de cursos a distancia -por correo postal- cuya promesa de éxito (sobre todo económico) tentó a más de uno y que, por ejemplo, te abrían las puertas al fascinante mundo de la imagen sólo a través de un curso de dibujo (que se anunciaba justo al lado del curso de detective privado), impreso por una editorial de dudosa procedencia en manuales tan arcaicos y elementales como la revista donde se publicitaban (y como el diploma que entregaban), con un complicado sistema de evaluación que obviamente implicaba aguardar pacientemente todo el tiempo que insumía la ida y vuelta postal de los exámenes, y todo administrado en dosis tan espaciadas 
que aprender a dibujar era sencillo comparado con el esfuerzo de sostener en el tiempo el sistema de aprendizaje. Ese diploma era el único papel enmarcado que colgaba en su cuarto.

\section{9 años}

Su primer encuentro con la fotografía se dio en una fiesta de cumpleaños de una tía (¿festejaría sus treinta años?) en lo de unos amigos a los que no conocía, donde el dueño de casa, joven profesional dedicado al comercio, amante del medio fotográfico y con práctica regular, se encontraba registrando el evento con una vieja réflex (entonces nueva), con un luminoso teleobjetivo corto y un potente flash de barra, un flamante equipo que calificaba sobradamente a su orgulloso dueño para trabajos de fotografía de eventos sociales como el que se encontraban, y aún de mayor magnitud. Siendo junto a su hermana los únicos niños presentes en una fiesta de grandes en una casa de grandes, luego de haber presenciado por más tiempo del que soportaba el transcurso de la fiesta, luego de haber mirado detenidamente todo el entorno y a todos los concurrentes (lo cual no dejó de parecerle fascinante: esa decoración, el modo en que se vestían y los peinados que usaban...), el amigo de la tía, buen anfitrión, al detectar los primeros síntomas de tedio infantil y con claro propósito de entretenimiento didáctico, le presta la cámara fotográfica. Hubo un antes y un después de ese momento -pensó más tarde, entre sueños, no con esas palabras, en el auto regresando a casa con su familia-. Y más tarde -más adelante en el tiempo, años después- siguió verificándolo. Fueron sólo dos fotos, dos disparos, que lo dejaron con una extraña sensación corporal, aunque no hubiera podido definirla. Cámara pesada. Demasiadas instrucciones en poco tiempo y en un clima poco propicio para entender algo: -Colgatela. Mirá por acá. Girá acá, y cuando veas nítido, dispará con este botón. Su clásica educación pública barrial no lo había preparado para esto. El claro recuerdo de no saber a qué se refería con nítido, si cuando veía bien lo que estaba cerca, lo de atrás se volvía borroso, y cuando veía bien lo de atrás, aquello que estaba cerca sólo era una mancha difusa (aunque tampoco conocía este término), y encima esta cámara que cuesta tanto sostenerla, pero qué grande y brillante se ve... De esa experiencia quedaron dos imágenes: primerísimos primeros planos de su madre y de su hermana con cara de no saber qué hacer ante la cámara, en blanco y negro copiadas sobre una especie de cartulina ultrabrillante que le confería un valor distintivo al resto de las fotos-pocas- que para aquel entonces había manipulado, y que fueron acercadas por la tía del cumpleaños varios meses más tarde, reavivando el recuerdo de la experiencia olvidada al poco tiempo.

$\mathrm{El}$ acontecimiento social era registrado por una única cámara fotográfica operada por un posible entusiasta que generalmente maniobraba rudimentariamente el aparato. La imagen para la posteridad del evento "no ritual" -esto es, que no exigía la convocatoria de un profesional- estaba librada a una cantidad de variables indómitas que cada tanto entraban en sincronía y permitían un resultado, aunque más no sea, legible, y desataba a posteriori, a partir del simple pedido de una copia por parte de cualquiera de los participantes, un arduo trabajo colectivo que, como los cursos por correspondencia, había que sostener en el tiempo: selección/edición - ¿dónde está el negativo de la foto de fulanito?-, traslado al laboratorio para la entrega, días de espera, nuevo traslado para el retiro, costos por copia, oportunidad de entrega al solicitante, etc.; trabajo donde, además, no todos los que actuaban tenían interés directo con "lo fotografiado" (los empleados del laboratorio, que participaban del proceso, totalmente anestesiados en un océano de imágenes, ya ni las percibían). En toda la escasa producción que en tal situación se generaba y que difícilmente superaba la medida de un rollo de película, había un desperdicio increíble, semejante al forjado por la superabundancia digital: en la 
actualidad hay tantos registros individualizados del mismo evento -que pronto olvidaremos- que nadie necesita pedirle copias de las fotos al anfitrión, garantizando, además, no tener que compartir el cuadro con los desconocidos o indeseables que siempre aparecían en las aisladas fotografías colectivas que lo eternizaban.

\section{0 años}

El año siguiente estuvo marcado por un episodio que le abrió los ojos a toda una nueva visión de la que tampoco se olvidaría, y que luego creería recordar cíclicamente al observar las prácticas de algunos fotógrafos con los que tomaría contacto. La excursión con su grado al Museo Nacional de Bellas Artes fue sin lugar a dudas una experiencia única, no sólo porque jamás se volvió a repetir en todo el resto de su educación primaria, sino porque la insistente presencia de desnudos femeninos en las obras allí exhibidas, sumada a las conspicuas observaciones de sus compañeros comentadas al oído, le permitió suponer durante mucho tiempo que el arte era la manera consentida de desnudar mujeres y mostrar orgulloso los resultados de la experiencia. La maestra de plástica de su escuela, promotora de la visita, acompañó al grado, y se ocupó de comentar ante su pequeño auditorio, que se encontraba entre sorprendido y divertido frente a las importantes obras de arte de la colección -tan realistas y naturales-, algunos de los pormenores de la tarea de pintores y escultores. La elaborada técnica de los maestros decimonónicos, los datos aportados por la maestra y la pobre iluminación que envolvía los cuadros le conferían a las imágenes representadas un mórbido realismo fotográfico que ese día sólo le permitió concluir lo siguiente: que modelo vivo se llamaba a las mujeres completamente desprovistas de ropas frente a las que los artistas pasaban largas sesiones observándolas del mismo modo clínico con el que él observaba la obra consumada, y que ese mirar era lícito (era artístico). Siempre le quedó la duda, ante la obra de algunos autores fotográficos que conocería más tarde, si en su pensamiento artístico adulto no siguen suponiendo lo mismo, pero sin la ingenua naturalidad infantil.

\section{2 años}

La única cámara fotográfica que existía en la casa era una pocket con película en cartucho de doce o veinticuatro fotogramas, regalo de la tía treintañera a la familia, con la que registró en esa cantidad limitada de imágenes su viaje a Córdoba al final de la escuela primaria, de la que su madre conservó únicamente la foto-foca donde aparecía solo y apenas distinguible en medio de otros excursionistas junto al enorme reloj cucú que constituía el fetiche local de la fotografía turística, paralelo mediterráneo de los lobos marinos marplatenses. Anécdota graciosa: todavía se tenía temor en permitir que un niño -ya entrando en la pubertad- lleve en un viaje ese tipo de cámaras cuyo valor monetario, incluso para ese momento, era bajísimo. El detalle importante de la fotografía turística era que si uno quería aparecer en la foto, tanto con ésta como con otras cámaras más caras, debía pedir a otra persona que dispare, entregando la cámara en mano a un desconocido ubicado a distancia prudencial de la escena.

\section{7 años}

Para el viaje a Bariloche de final de la secundaria, y como reconocimiento a una vida de estudio con éxito (aunque no se lo hayan dicho en esos términos) sus padres, atentos al interés que tenía por lo artístico, le regalaron ante su asombro una cámara réflex, con lente normal, y un flash compacto! Su 
felicidad se tradujo en las pocas imágenes que una semana después del regreso de ese viaje iniciático volvieron del laboratorio automático. A partir de la conversación sobre su pobre resultado-que igual lo llenaba de orgullo- con el hombre que atendía el laboratorio comprendió que, como su cámara no operaba automáticamente, debía prestar atención a los parámetros con que exponía, a qué película elegía, a cómo programaba el flash, a cómo se ubicaba en relación con la luz, a... Por suerte había comprado, al igual que sus veinticinco compañeros y a pesar del precio (como todo lo relativo a ese viaje, formidable negocio), la foto panorámica del grupo en el blanco cerro que el fotógrafo les entregó, montada en un bastidor un tanto ordinario, al día siguiente de su único ascenso a la nieve. En esa foto aparece con las proporciones exageradas que ese tipo de formato le reservaba a todo aquello que se ubique en los extremos del cuadro, y sin su cámara, que quedó en el cuarto del hotel por no contar con estuche para protegerla.

Una familia compraba una cámara réflex a partir del interés particular de alguno de sus integrantes (probablemente el padre, comisionado para producir las imágenes de la historia familiar que la madre se encargará de almacenar y difundir), y este único aparato -objeto singular dentro de una especie tecnológica muy homogénea que respondía a una línea de diseño consensuada por todas las marcas productoras de tecnología y que permaneció, en concepto, invariable hasta el cisma digital, que posteriormente lo emularía- era funcional a todos los miembros conforme crecía su interés o necesidad, a la vez que permanecía activo por décadas sin el más mínimo mantenimiento. El registro de aquellos eventos en los que no participaba el propietario del aparato conformaba una oportunidad única para iniciarse, a la vez que representaba un curso ultracondensado con práctica incluida, y cuyo resultado luego se sometería al juicio atento del propietario/profesor al paso y se compartiría con todo el entorno cercano presente en el evento, testigos del rito de iniciación a la vez que pacientes modelos de la sesión. En la actualidad cada miembro de la familia tiene posibilidades de generar sus propias imágenes fotográficas a través de cualquiera de los dispositivos de captura de imágenes con que cuenta el hogar actual, y compartirlas con todo aquel que quiera verlas en una suerte de culto a la intimidad pública, o abandonarlas en ese almacén depositario de experiencias en que se constituyó la computadora doméstica, todo con la misma urgencia propia de lo digital.

\section{8 años}

El mismo año se vio acompañando, casi sin pensar, a un amigo a un famoso test vocacional gratuito que se hacía en un manicomio (i?), donde un psicopedagogo le decretó una clara inclinación hacia la abogacía (i!), y a una amiga a la prueba de nivel de la primera escuela de fotografía que no era un fotoclub, en la que le recomendaron seguir un curso de iluminación avanzado. Había estado aprendiendo en el verano los rudimentos de la fotografía en general, y del laboratorio blanco y negro en particular, con un amigo que a su vez estuvo aprendiendo con un compañero de escuela que tenía un pequeño cuarto oscuro en la casa (toda una rareza, herencia, al igual que su equipo, de la época de aficionado de su padre). Las largas sesiones, amuchados en el laboratorio, alcanzaban el límite físico, y sólo concluían cuando se agotaba el papel (o las fuerzas para continuar trabajando parado). Toda esa experiencia le permitió saltearse el curso de iniciación y asistir directamente a uno de actualización y perfeccionamiento dirigido a profesionales, junto con un grupo de fotógrafos bastante mayores que él dedicados, en su totalidad, a fotografía de eventos sociales o de productos. Su falta de conocimiento orgánico sobre el medio casi le vale la expulsión del grupo. Había incorporado un montón de saberes durante ese verano dedicado en exclusividad a la fotografía, pero no era ni por 
asomo lo suficiente como para aprovechar todos los conocimientos impartidos por el profesor, un viejo fotógrafo editorial extremadamente riguroso, que por momentos explotaba ante lo inquieto de su único joven alumno. Debemos comprender que, como sucedía en algunos ámbitos de la educación en fotografía, este profesor, a pesar de la enorme experiencia que tenía, nunca había adquirido formación pedagógica. No obstante, ese mismo carácter inquieto le sirvió para que uno de sus compañeros de curso lo contrate como asistente en su estudio, donde tuvo oportunidad de asimilar, en tiempo récord, todos aquellos saberes que le permitirían operar con seguridad en las exigentes condiciones que el trabajo en un estudio profesional requería. Fue allí (en el curso, en la escuela) donde volvieron a resonar los ecos de un pensamiento de niño mientras sus compañeros analizaban, durante los recreos, los trabajos de aquellos que también hacían el curso de desnudo, o repasaban las monocromas páginas de la única publicación que mostraba la obra de los maestros nacionales (seguramente a canje de algún artículo con el que llenar contenidos editoriales) donde explicaban cómo sacarle "mejor partido" a las pobres condiciones -reflejo de pobres ideas- con las que trabajaban sacándole fotos -sacándole la ropa- a las modelos.

\section{4 años}

Formado en la disciplina fotográfica en un momento donde el nivel de conocimientos debía ser profundo - no del medio en general, sino sólo de la cota técnica necesaria para operar- y cursando sobre el final de una carrera profesional (que se volvería complementaria a su carrera artística) que le brindaba herramientas teóricas y conceptuales aplicables perfectamente al medio fotográfico, se propuso renovar el método de enseñanza de la fotografía, y para ello presentó un plan de estudios en la misma facultad donde cursaba. Por supuesto nunca nadie le había enseñado cómo elevar una propuesta en el ámbito académico, pero esgrimió un sólido argumento que finalmente le permitió poner en marcha su plan: la facultad vinculada con la imagen de la mayor universidad nacional no tenía a la fotografía ni como carrera ni como materia de alguna de las carreras que allí se dictaban (ni en las que después aparecieron). Su experiencia como buen alumno de la facultad y mal alumno de los cursos de fotografía que se ofrecían en ese momento le valió a la hora de planificar cómo debería ser la formación integral de un nuevo fotógrafo. Era consciente que la técnica no había sufrido modificaciones a lo largo de un siglo, por lo que sintió que se debía trabajar más en la forma que en los contenidos técnicos, y que se tenía que apuntar fundamentalmente a generar nuevos ejemplos de aplicación de esos recursos técnicos, aprovechando en este caso las condiciones naturales que disponían aquellos que elegían estudiar en esa facultad. Así, de paso, incorporaba todo el bagaje de teoría del diseño y las artes que se estaba divulgando a través de las materias de grado. Creía que había llegado el momento de acercar la fotografía a las otras disciplinas proyectuales, como posteriormente la creyó posible de incluir en las otras disciplinas del pensamiento. Propuso concebir cada foto como un diseño y cada trabajo como un proyecto (más allá de temas y géneros fotográficos), y olvidar momentáneamente algunos credos de la ortodoxia compositiva que idolatraba ejemplos concebidos durante un supuesto fugaz y decisivo instante que en la práctica equivalía a que suceda un milagro ante nuestros ojos (y que justo tengamos la cámara preparada apuntando en esa dirección). La salida de tomas el domingo a la mañana y el posterior concurso fueron erradicados. Así, cada alumno desarrollaba un ensayo fotográfico sobre un tema de su interés y ponía en práctica aquellos conocimientos incorporados en las clases teóricas de fotografía y de diseño, siendo acompañado por el profesor en el desarrollo de su propio trabajo. A través de ese seguimiento es que tuvo oportunidad de observar, 
en esas planchas de contactos, todos aquellos cambios que se fueron dando año tras año y que impactaron sobre una población que inicialmente representaba su propia generación y ahora ve como a aquel inquieto joven que una vez estuvo a punto de ser expulsado de un curso de fotografía.

\section{2 años}

Una imagen (click!) de esta época nos muestra cierto trabajo como asistente del titular del estudio en la boda de un futbolista campeón del mundo el año anterior, en un despilfarro antológico, teniendo que fotografiar durante toda una noche celebridades invitadas no pertenecientes al mundillo futbolístico, y que sólo conocían al novio, como todo el mundo, por su participación en el equipo mundialista. El contraste entre la disposición a las cámaras de aquellos invitados del mundo del espectáculo, y los humildes familiares de los novios, era notable. En varias de esas estampas vio las mismas caras que su madre y su hermana intentaron ante su primera foto. La feliz pareja era un vivo retrato de silenciosa desesperación ante la fastuosidad y el protocolo de la fiesta de la cual eran los anfitriones. No pudo presenciar en su totalidad el aparatoso evento porque tuvo que correr al estudio a revelar todos los rollos que habían hecho hasta el momento para el álbum de bodas (porque, en caso de fallos, la fiesta continuaba) y para las revistas (que querían la primicia para cuando la fiesta termine).

Antes, las principales fiestas rituales exigían contar con el concurso de un equipo de profesionales que se ocupe del registro pormenorizado de la misma, y en lo posible incluyendo la aplicación de recursos creativos de catálogo. A su vez, era la oportunidad de iniciarse comercialmente en la actividad fotográfica tentando a conocidos con precios módicos para que lo contrataran como fotógrafo de eventos, sin tener conciencia del riesgo que todos asumían. Más de uno se ha quedado sin álbum de casamiento. En la actualidad, cada uno se hace las fotitos que quiere con lo que inicialmente era un teléfono personal, y que ahora no sólo filma y graba voz e imágenes estáticas en una calidad inimaginable para su feliz portador, que aún no lo terminó de pagar en cuotas, sino que además le permitirá editarlo con más efectos creativos de catálogo, tornándolo súbitamente artístico, y enviárselo al aparato (igualmente encendido) del anfitrión durante el mismísimo transcurso de la fiesta. En vivo y en directo.

\section{0 años}

El casamiento como el evento más encumbrado del ceremonial social de una familia, para el cual seguimos convocando profesionales tanto para su organización como para su registro. El álbum de casamiento como último álbum, como último cuaderno de apuntes de una vida -o de dos, en este caso, a las que se les sumaría las de los asistentes a la fiesta-. El amigo aficionado que registró el evento y que con voluntad regala a la feliz pareja, algunos días después de la boda -demasiados, para los radiantes espososun álbum de tapas duras con las imágenes en un tamaño mayor que la copia comercial regular.

\section{El cisma digital}

El cisma digital lo encontró establecido en la ciudad de Buenos Aires, dedicado a enseñar, investigar y producir su obra artística teniendo todavía como soporte exclusivo de estas actividades la fotografía, y a la vez desarrollando un sinfín de otras actividades que le permitiera hacer frente a las variables económicas a las que todos los habitantes de esas tierras están acostumbrados. Esas otras actividades tenían relación con la fotografía sólo tangencialmente (y no siempre) y debían ser desarrolladas 
debido a que ni la actividad académica, ni la artística daban oportunidades de vivir dignamente, a pesar de los múltiples esfuerzos que en esos campos de acción había brindado y ciertos logros que había obtenido. Ese cisma tecnológico mencionado alude al nuevo paradigma de producción y reproducción de sonidos e imágenes que, del mismo modo que el cisma religioso dividió Occidente, este dividió al mundo, pero no por creencias sino por consumo. Al momento del cisma ya se había experimentado un determinado cambio con el video magnético, que en su génesis incluía, entre otras cosas, la idea de apartarse de los procedimientos químicos para producir imagen visible. Este factor llamó rápidamente su atención, detectando en este nuevo medio, tan diferente a la fotografía -donde se había educado- algunos atributos que lo volvían indispensable para transmitir ciertas inquietudes de ese momento. Una lectura posterior del medio le permitió concluir que el video envejece más rápidamente que la fotografía quien, como un Dorian Gray, conserva una imagen que soporta todavía la visión devuelta en el espejo del tiempo, que en innumerables casos le otorga, encima, un carácter aurático muchísimo mayor que el que contaba en el momento de haber sido producida. El video, con sus saltos de calidad de imagen producto del soporte magnético utilizado, sus problemas de conservación y sus dificultades de reproducción debido a la obsolescencia de los aparatos que nos devolvían esa otra imagen en ese otro espejo (en la pantalla) se vio cada vez más envejecido, sobre todo comparado con esos jóvenes formatos que aumentaron geométricamente los atributos de belleza (de calidad) en las imágenes que producían. Probablemente esa lectura le permitió volverse más observador de todo aquello que fue pasando en esto que podríamos llamar su formato nativo -su lengua madre-, ese medio en el cual se había educado a pesar de todos los inconvenientes que ello supuso para una persona naturalmente curiosa e inquieta que nunca cesaba de indagar en otros campos (de la imagen, del pensamiento) más allá de las dos disciplinas en las que se formaba simultáneamente. Desarrollar dos disciplinas simultáneas fue casi una condición sine qua non en esa época de formación: no había estudios formales sobre fotografía -los métodos de enseñanza estaban diseñados por profesionales fotógrafos sin capacitación docente-, con lo que los contenidos pedagógicos de estos programas de estudio adolecían en su mayoría de tantas carencias que sólo lograban como resultados educar a las personas en una ortodoxia que durante mucho tiempo impidió que el género se expanda forjando nuevas corrientes o acompañando las que se estaban sucediendo en otras latitudes. Tampoco había publicaciones específicas, y las que aparecían representaban un tremendo esfuerzo individual que uno se veía en la obligación de acompañar aunque más no sea para que no se extingan, a pesar de no encontrar nada en ellas que cautivara ni en los contenidos ni en la calidad de reproducción a la que accedían, y esto en el caso de que el presupuesto de edición brindara la posibilidad de imprimir imágenes, muchas de ellas reducidas de color a un modesto ejercicio tonal que casi siempre atentaba contra esas pocas reproducciones. Podríamos pensar que, en relación con el estudio de la fotografía, sólo quedaba la posibilidad de aprender la técnica que la tecnología de ese momento (sostenida en el campo fotográfico casi sin variantes durante lapsos eternos), y complementarla con toda la investigación personal que el campo de la teoría de la imagen posibilitaba a través de fotocopias de baja calidad y de cuarta mano, en idiomas que uno no manejaba, y por sobre todas las cosas sin imágenes, o con una alteración tal de éstas, producto de las tres o cuatro fotocopias que el documento había sufrido con anterioridad a nuestro encuentro, que se podría decir que eran otra. Muchas veces el encuentro posterior con las mismas imágenes reproducidas impecablemente -tanto como el cisma tecnológico permitió en el campo editorial al generar un boom de los libros de/ con imágenes- condujo a una inevitable decepción: aquello que había leído, aquella obra que había visto en esa imagen raída era esto. Esta situación también pudo haberlo conducido a vincularse con 
la escritura como lenguaje visual: haber estudiado la imagen sólo con textos le permitió encontrar un espacio, inicialmente vinculado con la literatura, donde describir lo imaginario, y de allí directamente pasar a construir un pensamiento ligado con la posibilidad de plasmar en fotografías, en imágenes técnicas, ciertas cosas que no existían previamente, ciertas ficciones. Una educación a través de metáforas. Por supuesto que se trató de una educación autogestiva, autodidacta, que fue tomando forma conforme aparecían nuevos intereses sobre los cuales era necesario aprender algo más. Errática, con escasos ejemplos de los cuales valerse. Ese mismo método del no método es el que lo impulsó durante todo ese tiempo a indagar en otras formas de expresión para las que no había recibido capacitación alguna, y que abordaba de un modo que podría llamarse experimental, pero que era más bien como si uno pretendiera operar un sofisticado aparato, por ejemplo un avión, sin haber manejado previamente siquiera un simulador de vuelo.

\section{1 años}

Haber vivido el cisma digital en la Argentina del cambio de siglo le permitió ser testigo de una especie de inmolación colectiva que luego denominaría el holocausto analógico: a medida que el país se sumergía en una crisis sin precedentes, que ubicaba el valor de la moneda de un día para el otro a la tercera parte, muchos fotógrafos sacrificaban sofisticados equipos para película a precios de remate con el objetivo de recibir algo del dinero que necesitaban en ese momento para adquirir equipamiento digital a precios internacionales, accediendo a cámaras que si bien les permitieron inicialmente pertenecer a la nueva ola digital, resultaron obsoletas muchísimo más rápido de lo que imaginaban, viéndose en la necesidad de cambiar en un lapso brevísimo de tiempo no sólo la cámara digital recientemente adquirida, cuya capacidad y resolución había quedado fuera del estándar que les permitiría seguir en competencia dentro del circuito comercial, sino también las computadoras con las cuales operaban, debido a la rápida escalada que fueron dando los formatos en cuanto a peso de los archivos. Todos estos operadores, formados en la ortodoxia fotográfica, con costosos aparatos y laboratorios equipados a lo largo del tiempo que duró la técnica tradicional de la fotografía química (toda su vida), se vieron obligados a adaptarse rápidamente a un nuevo mundo marcado por la impronta binaria, donde tuvieron que volver a equiparse para poder introducirse en las nuevas maneras de producir imágenes, y así aprender a operar un sistema totalmente diferente al que recibieron como educación y en el que habían logrado un cierto cúmulo de experiencia, lidiando con nuevos métodos, técnicas y lenguajes a una velocidad que muchas veces iba a contramano de las posibilidades intelectuales y de concentración que dicho cambio requería, obligando no sólo a sacrificar el equipo que tanto había costado sino también a consagrarse ellos mismos en el esfuerzo superlativo que el nuevo lenguaje demandaba. A eso se le sumaba el avance de una generación digital nativa a la cual la adaptación no le demandaba ningún esfuerzo, en una natural asimilación de los procesos que iban acaparando cualquier operación dentro del cambiante campo de la comunicación y la imagen. Al sólo conocer este nuevo lenguaje, al ser su lengua madre, el constante esfuerzo de incorporación resultó con una naturalidad que se opuso fuertemente a la artificialidad del abrupto cambio operado para las generaciones anteriores. Para colmo de males, el rol docente enfrentaba constantemente a nuestro personaje al debate de cada nueva variable dentro del campo de la imagen digital con sus naturalmente capacitados interlocutores, demandándole un esfuerzo extra de formación y actualización para estar a la corriente de todas las novedades que día a día se fueron dando en este campo, y que seguramente tendría que explicar a sus ávidos alumnos. 


\section{9 años}

Habiendo comprendido que el cisma digital recién empezaba a mostrar sus consecuencias (a pesar de que aún no se percibían los aspectos negativos del asunto, como el radical desplazamiento que produjo de todo aquel que no logró adaptarse, volviéndolo en una primera fase anacrónico, y en la etapa terminal analfabeto), y luego de mucho tiempo de esfuerzos, logra comprarse una computadora. Después de meditarlo en profundidad -lo que significó enfrentarse a una abrumadora gama de posibilidades, todas de una complejidad que lo superaba, en un mercado completamente nuevo del cual no se podía evaluar entonces una proyección a futuro, sin tener referentes a los cuales consultar ya que todos gozaban de la misma inexperiencia y por sobre todas las cosas, con un monto disponible que no le dejaba demasiado margen para equívocos- se decidió por una que suponía mejores prestaciones para el ámbito gráfico, que estaba estrenando compatibilidad con las plataformas más corrientes y con los sistemas operativos más difundidos (en un inútil intento de aplacar la esquizofrenia que empezaba a invadir a los usuarios), y que tenía un aura de exclusividad diseñada bajo los mismos parámetros que su entorno físico, lo que le agregaba una cuota de satisfacción a la compra que justificaba la diferencia de precio con un producto de similares prestaciones, pero desangelado. Para el momento en que cayó en la cuenta de lo rápido que se movía el mercado digital, decretando sistemática y regularmente la obsolescencia de todo aquel producto que cumpliera su primer año de vida, su computadora valía menos de la cuarta parte del precio de compra, por lo que ya no se justificaba su venta, y como se trataba de un sistema que simbolizó un punto de inflexión hacia los equipos de más alto rendimiento que llegarían un par de años más tarde, tampoco su actualización. Esta situación, novedosa para todo aquel usuario de equipamiento que, como las cámaras réflex, no nacían con certificado de defunción ya que eran eficaces durante toda una vida, lo condujo a concluir que cada nuevo producto de la tecnología, en el mismo acto de su lanzamiento asiste al funeral de sus antepasados, apenas más viejos que ellos, y en su tecnológica conciencia carga fugazmente con el peso de haberlos liquidado, o el secreto orgullo de haberlos superado, pero sólo hasta que otro nuevo producto lo inhume, momento a partir del cual esos sentimientos se transformarán en la paciente espera de la revancha que el solo paso del tiempo le presentará, ya que la posibilidad actual de remedar la genealogía de la tecnología es nula: de ahí la inviabilidad de reproducir las grandes obras tecnológicas de un pasado reciente para que operen en idénticas condiciones que sus originales, y la dificultad de conservar las que aún funcionan. Y a pesar de esto, las multinacionales de tecnología con sede en Oriente continúan produciendo por miles las miles de novedades que ya nadie les pide, desbordados como estamos acatando sumisamente la voraz renovación tecnológica y esforzándonos por adaptarnos a ella, $\mathrm{o}$ acomodándonos confortablemente en el amasijo de estímulos al que le abrimos nuestras puertas cada día a través de un sinfín de aparatos que cada día nos exigen una dosis más fuerte (de tecnología y de estímulo) en una adicción que nos vuelve inoperantes y que los convierte en nuestra droga más efectiva para evadir nuestra realidad cotidiana, que nos sigue mostrando tal cual somos.

En la actualidad, y a pesar de que funciona -esto es, enciende y opera- esa computadora se encuentra decorando una vitrina que ocupa una pared de su estudio donde almacena todos aquellos aparatos que fue comprando con el entusiasmo propio de quien pretende mantenerse actualizado y que se vio forzosamente obligado a abandonar -a medida que el mercado los tornó obsoletos a pesar de seguir desempeñando sus funciones-, en un rincón que constituye algo así como un cementerio de la tecnología, que no cesa de sepultarse a sí misma. Allí podemos ver: la computadora -power PCmencionada (origen: China, bajo licencia de una firma de EEUU) con el monitor de catorce pulgadas 
(origen: Corea, con la misma licencia), una unidad de memoria externa de quinientos megabytes (Malasia), una lectora de discos zip (Malasia) y otra de discos jazz (Filipinas), una impresora color (Corea) cuyos cartuchos ya no se fabrican, una calculadora científica con números luminosos rojos y batería recargable (EEUU) que data de su secundaria, otra que no es ni más ni menos que la primera calculadora portátil que se fabricó en el país (Argentina), una videocámara VHS C (Japón), una videocámara Hi8 (Japón), una editora de video analógica (Taiwan), dos reproductores de videocasetes -con control remoto- de diferentes normas (origen: Argentina, con componentes de diferentes regiones de Asia, y Malasia), una filmadora súper ocho (Alemania), el proyector súper ocho (Alemania), un proyector de diapositivas portátil (Alemania), una cámara fotográfica de formato medio de doble objetivo (Alemania), una cámara fotográfica réflex mecánica con motor y tres ópticas (Japón), una réflex electrónica con otras tres ópticas (Malasia), un visor estereoscópico para diapositivas que nunca usó (Francia), un teléfono inalámbrico (Japón), dos teléfonos celulares enormes (China), un autoestéreo a casete (Japón), un walkman (Japón), un discman (Japón), dos radiograbadores -uno de doble deck- (Japón, Malasia), dos contestadores automáticos a casete -uno de casete común y otro de un modelo mini- (Japón, Taiwan), dos deck a casete (Japón), un grabador de cinta abierta de dos pistas (Japón), una bandeja giradiscos (Taiwan), un reproductor de videoláser (Taiwan) con los únicos cuatro discos de video que llegó a comprar, un televisor color portátil de catorce pulgadas (Brasil), un aparato para ver todos los canales de cable que no me acuerdo ni cómo se llama...

\section{(Al día de) Hoy}

Escribir sobre la fotografía, poner en palabras la imagen, como si la imagen, por sí sola, no bastara. Pero como mi educación fotográfica me entrenó para poner las ideas en imágenes, ésta es la fotografía.

Summary: This exercise of descriptive writing could be interpreted, of some way, as an attempt to freeze a moment (as in a photography) of historical confusion, that quickly forgets or leaves all that is unregistered and if registered will happen to be one more of those many things that on a daily basis ask to shouts that we render to them a little attention in the middle of an universe of stimulation whereupon we coexisted. Or also, as it would deal with things of the past, could be read as a possibility of bringing to present a series of stamps that would allow us to recreate the history of a certain character who involves other ones history. It would be something like plunge in a photo album to reconstruct the script of its life to undertake the one of its social group. Text has been organized inshort chapters, that were entitled by our character's age to the moment at which the experience is narrated, that may not be chronological, and that in case of turning on general questions of its life, like for example the origin country, can directly take the name of the subject that is boarded.

Keywords: digitalis - education - image - photograph - schism - technology.

Resumo: Este exercício de escritura descritiva poderia interpretar-se, de algum modo, como uma tentativa de congelar um instante (como numa fotografia) de um momento histórico confuso, mutante, que rapidamente esquece ou abandona a sua sorte tudo aquilo do que não se leve registo, e que se se registra passará a ser uma mais das tantas coisas que a diário nos pede a gritos que lhe prestemos um momento de atendimento no meio do universo de estímulos com do que convivemos. Ou (também), como trataria de coisas do passado, poderia ler-se como uma possibilidade de trazer ao presente uma série de estampas que nos permitiriam recrear a história de um determinado personagem que parabólicamente envolve 
a de variados. Algo bem como remexer em seu álbum de fotos para reconstruir o roteiro de sua vida para empreender o de seu grupo social.

Também, para organizar o relato, divide-se o texto em pequenos capítulos, que levam como título a idade do mosso personagem ao momento em que conta-se a experiência, que podem não ser cronológico, e que no caso de fazer referência a questões gerais da sua vida, como por exemplo o pais do origem, pode levar diretamente o nome do tema que aborda.

Palavras chave: cisma - digital - educação - fotografia - imagem - tecnologia. 